\title{
Does the corporate life cycle affect earnings management? Evidence from Central European countries
}

\author{
Lucia Michalkova, ${ }^{1, *}$ \\ ${ }^{1}$ Department of Economics, Faculty of Operation and Economics of Transport and Communications, \\ University of Zilina, Univerzitna 1, 01026 Zilina, Slovakia
}

\begin{abstract}
Research background: Earnings manipulations are a global phenomenon, the aim of which is not only to improve the financial position in accordance with Positive Accounting Theory, but also other goals of the company in accordance with the management strategy. However, the diversity of the company's goals along with the corporate life cycle are crucial factors influencing the quality of corporate earnings and the existence, scope and application of downward and upward earnings management.

Purpose of the article: The aim of the paper is to comprehensively analyse and verify the existence and extent of downward and upward earnings management in Central European countries with an emphasis on differences between countries and between life cycle stages.

Methods: The study uses Mann-Whitney test and binomial test to verify the existence and extent of downward and upward earnings management. The sample covers discretionary accruals for 2019 estimated by modified Jones and Teoh, et al. models from almost 3,500 companies from four Central European countries.

Findings \& Value added: The results show that, depending on the life cycle stage or country, companies manipulate profits, but the application of a specific type of earnings management and its scope vary significantly within countries and life cycle stages. Lifecycle manipulation earnings are Ushaped, meaning that start-ups and declining companies use, on average, more significant upward earnings management. On the contrary, mature companies reduce their accounting profit. Nevertheless, the share of companies using upward earnings management is higher than companies with downward earnings management.
\end{abstract}

Keywords: corporate life cycle; discretionary accruals; emerging economies; earnings management

JEL Classification: $G 31 ; G 32 ; H 43$

\footnotetext{
${ }^{*}$ Corresponding author: lucia.michalkova@,fpedas.uniza.sk
} 


\section{Introduction}

The current global economic situation, combined with a shortage of raw materials, rising inflation and recurring lockdowns, poses a major challenge for businesses. From the beginning of the coronavirus health crisis, deteriorating corporate conditions and growth in corporate defaults have been forecast. Businesses often use earnings manipulation in an unstable economic environment and at risk of default, as documented during the 2009 financial crisis by Lisboa and Kacharava (2018). This attitude is related to the application of Positive accounting theory, assuming that managers use various accounting techniques and manipulate financial statements in order to make their own profit (Watts and Zimmerman, 1986). Last but not least, managers are motivated by other factors such as reducing tax liabilities, shifting revenues from good years to bad years or prolonging the trend of good results into the future with a delay in disclosing losses (Iatridis, 2010).

In addition to the factors mentioned above, there are other influences that play a significant role in the quality of reported profits. Various empirical studies (Michalkova, 2021, Hussain, et al., 2020 or Habib and Hasan, 2017) show that the life cycle of a company has a significant impact on the degree of accounting manipulation in relation to creative accounting. Suberi, et al. (2012) say that growing businesses are increasingly applying earnings management techniques, Can (2020) notes that growing and mature businesses tend to manipulate accounting more aggressively to minimize revenue.

The studies mentioned above, together with factors in the current macroeconomic environment, indicate that the life cycle has a significant impact on earnings management. Nevertheless, a more detailed analysis of earnings management within the corporate life cycle to the best of our knowledge has not yet been performed. The aim of this study is a comprehensive analysis of the existence and extent of downward and upward earnings management within Central European countries with an emphasis on the corporate life cycle. The net sample contained almost 3,500 Central European enterprises and data on their discretionary accounting accruals for the last available financial year 2019, which is most relevant to the current economic situation. Discretionary accruals were estimated based on modified Jones and Teoh, et al. models for examining total and short-term discretionary accruals. Dickinson (2011) non-sequential life cycle model was used, which allows, unlike other used life cycle models, to examine its impact on small and medium-sized non-traded enterprises. Two methods were chosen as appropriate to meet the aim of the study: MannWhitney to verify the existence of earnings management and a binomial test to test whether downward or upward earnings management predominates within the life cycle stages within Central European countries.

\section{Literature review}

Earnings management is defined in various ways, McKee (2005) emphasizes the legal nature of accounting manipulations in order to achieve certain goals of accounting reporting. Kramarova and Valaskova (2020) determine how these goals e.g. reduction of tax liabilities, achievement of more advantageous debt covenants or growth of corporate value. Svabova, et al. (2020) combines tax avoidance with fraudulent financial reporting and downward earnings management. However, financial statement fraud cannot be associated with every fraudulent accounting, which underscores the legal aspect of earnings management activities.

In the Central European aspect, earnings management is less explored than in developed markets. Kliestik, et al. (2020) points to the growing trend of earnings manipulations in all Central European countries with a threshold value in 2014. Valaskova, et al. (2021) on the other hand points to the difference in earnings of manipulations between industries. In addition, the size of the company is an important factor for the value of the discretionary 
accruals of Hungarian companies, while the age of the company and the ownership structure is an important distinguishing factor for Polish companies. Lizinska and Czapiewski (2018) attribute the low quality of profits to the IPOs of companies associated with significant upward earnings techniques. Savova (2021) examined accounting standards in Bulgaria and found that the accounting system in Bulgaria complied with international IFRS standards, which reduces the scope for accounting manipulations. Sadiq et al. (2020) adds that the relationship between corporate governance and profit quality is positive.

There are several views on the corporate life cycle, managerial perception or the view of corporate finance such as dividend policy, business valuation or managerial accounting are the most common (Gray-Hawkins and Lazariou, 2020; Siekelova et al., 2021). The business life cycle theory is based on product life cycle assumptions, the company is considered a mix of different company products and other factors. Therefore, applying a product lifecycle to a business is inefficient because the business is a combination of internal, external factors, and the allocation of business resources (Dickinson, 2011).

There are several life cycle models such as Damodaran (2018) or Dickinson (2011). The latter method is one of the most widely used because it uses cash flow patterns (unique combinations of operating, investment and financial cash flow). The model assumes that cash flow comprehensively absorbs internal and external influences, including the company's experience resulting from the company's age, which allows abstracting from the sequential progress of the company through stages. This model assumes five stages: Introduction, Growth, Maturity, Shake-out and Decline.

Start-ups are mostly financed by bank debt and to a lesser extent by equity (Kramolis and Dobes, 2020), which is associated with high cost of debt, credit risk. Uncertainty and volatility of profit or cash flow is significantly higher at this stage (Habib and Hasan, 2017) together with the risk of default. In terms of accruals, working capital accruals are the highest, while low depreciation reduces this type of accruals.

Growing businesses reduce both operational and default risk. Businesses reach a breakeven point, operating cash flow is positive, but profit still lags behind sales. The value of total accruals is high because the value of fixed assets as well as depreciation is the highest. Compared to start-ups, a growing business is more profitable and less indebted, which is reflected in the effort to increase accounting profit and positive discretionary accruals (Hussain, et al., 2020).

As in the case of the industry life cycle, mature companies achieve maximum operating profit as well as maximum positive operating cash flow. There is a significant difference between cash flow and profit, with cash flow outpacing profit. Corporate risk is minimal, which minimizes all types of costs, including capital costs and operating costs. Working capital accruals are low because investment in current assets is minimal Damodaran (2018) notes that mature companies, despite a stable position, prefer internal financing, which, however, creates pressure from shareholders to report high profits and pay dividends.

A shake-out company is characterized by a gradual decline in profitability compared to mature companies, which is reflected in a decline in stock prices. Dickinson (2011) uses this stage as a supplementary because there is no clear record of what the cash flow patterns are at this stage. A frequent goal of the company at this stage is to reverse the life cycle or, conversely, to slow down operating activities, sell fixed assets and increase investment cash flow. Habib and Hasan (2017) use this stage as a benchmark to interpret other stages of the corporate life cycle.

Declining businesses usually have much lower production power, which is reflected in negative operational cash flow, low sales and as well as profits. The cost of capital is high but lower than for start-ups because debt is reduced. Investment cash flow is positive as the value of fixed assets gradually decreases and accruals from depreciation are minimal (Bilan, et al., 2020). Edwards, et al. (2016) note that low liquidity and the risk of financial distress 
can create space for tax avoidance practices and thus for downward earnings management techniques.

Within the corporate life cycle, there are significant changes in financial performance and thus in the creation of variously wide space for earnings manipulation. Hussain, et al. (2020) examined the degree of earnings management in the context of Chinese listed companies. They argue that companies in the Introduction and Decline stages handle earnings significantly more than growing and mature companies, which use earnings management techniques only to a small extent. They justify the high level of both accrual and real earnings management by obtaining bank loans with advantageous debt covenants, which agrees with the conclusions from Kramarova and Valaskova (2020). They add that start-ups and declining of corporate profits are more manipulated upwards; on the contrary, growing and mature companies are applying downward earnings techniques to a greater extent. Zamrudah and Salman (2013) argue that accrual earnings management is important for growing companies, while declining companies use real earnings management to a greater extent, which may be more difficult to identify. Dickinson (2018) draws attention to the need for quality accounting information in the Introduction and Decline stages, which indicates a high degree of accounting manipulation in these stages.

As the studies in the previous paragraphs show, financial indicators of companies vary over the life cycle, including discretionary and non-discretionary accruals. However, these studies focus primarily on listed companies that are not dominant in Central European countries. Based on these studies, we can list the hypotheses examined in the next section of this paper:

H1: Businesses in Central European countries handle earnings.

H2: Central European companies manipulate earnings differently across life cycle.

\section{Methods}

The aim of this study is a comprehensive analysis of the existence and extent of earnings management, or downward and upward earnings management within Central European countries within the life cycle of the company. The life cycle is described according to the Dickinson (2011) model based on the assumption that cash flow absorbs all relevant influences that distinguish the stages of the life cycle from each other. There are eight different combinations of operating, investment and financial cash flow that correspond to the five stages of the life cycle. These cash flow patterns are given in Table 1.

Table 1 Corporate life cycle and their cash flow patterns

\begin{tabular}{|l|l|l|l|l|l|l|l|l|}
\hline Cash flow & Introduction & Growth & Mature & \multicolumn{3}{|c|}{ Shake-out } & \multicolumn{2}{c|}{ Decline } \\
\hline Operating & - & + & + & - & + & - & - & - \\
\hline Investing & - & - & - & - & + & + & + & + \\
\hline Financing & + & + & - & - & + & - & + & - \\
\hline
\end{tabular}

Source: Dickinson (2011)

Earnings management can be detected in various ways, the most common being models of accrual and real earnings management. Two models were selected, a modified Jones model and Teoh, Welch and Wong model (Teoh, et al. model). The former is one of the most widely used and its accuracy has been tested in the conditions of Central European companies (Kliestik, et al., 2020). Model by Teoh, et al. (1998) focuses mainly on short-term discretionary accruals. Discretionary accruals calculated as residuals represent a proxy for earnings management practices. If the discretionary accrual is positive, the company applies an upward earnings management and, conversely, a negative accrual is a sign of an 
accounting decrease in earnings. The formulas for the earnings management models, including the total accrual, used in the study are given in Equations 1-3.

$$
\begin{gathered}
\mathrm{TA}=\Delta \mathrm{CA}-\Delta \mathrm{CL}-\Delta \text { Cash }+\Delta \mathrm{STD}-\mathrm{Dep} \\
\frac{\mathrm{TA}_{\mathrm{it}}}{\mathrm{A}_{\mathrm{it}-1}}=\alpha_{0} \frac{1}{\mathrm{~A}_{\mathrm{it}-1}}+\alpha_{1} \frac{\Delta \mathrm{REV}_{\mathrm{it}}-\Delta \mathrm{REC}_{\mathrm{it}}}{\mathrm{A}_{\mathrm{it}-1}}+\alpha_{2} \frac{\mathrm{PPE}_{\mathrm{it}}}{\mathrm{A}_{\mathrm{it}-1}}+\varepsilon_{\mathrm{it}} \\
\frac{\mathrm{A}_{\mathrm{it}-1}}{\mathrm{~A}_{\mathrm{it}}}=\alpha_{0} \frac{1}{\mathrm{~A}_{\mathrm{it}-1}}+\alpha_{1} \frac{\Delta \mathrm{SALE}_{\mathrm{it}}-\Delta \mathrm{REC}_{\mathrm{it}}}{\mathrm{A}_{\mathrm{it}-1}}+\varepsilon_{\mathrm{it}}
\end{gathered}
$$

Where $\triangle C A$ - change in Current assets, $\Delta C L$ - change in Current liabilities, $\Delta$ Cash is change in Cash, $\triangle S T D$ - change in Short-term debt, Dep - Depreciation, $T A_{i t}$ - Total accruals in year t, $A_{\text {it-1 }}$ - Assets in year t-1, $\Delta R E V_{i t}$ - change in Revenues, $\triangle R E C_{i t}$ is change in Receivables ; $P P E_{i t}$ - Property, Plant and Equipment in year $\mathrm{t}, \triangle \mathrm{SALE}_{\mathrm{it}}$ - total sales in year $\mathrm{t}$.

Two statistical tests were used to verify the existence of earning management: MannWhitney $U$ test and the binomial test. The Mann-Whitney $U$ test is the non-parametric equivalent of a two-sample t-test to verify the equality of the mean values of two samples. In this study, the test is used to verify the existence of earnings management in Central European companies. Two samples are compared: discretionary accruals from real business samples and fictitious sample, where discretionary accruals are close to zero. The null hypothesis states that both samples have the same distribution, i.e. the mean value of the discretionary accruals of real enterprises is zero and these enterprises do not manipulate earnings. An alternative hypothesis is that companies manipulate earnings because the mean value of discretionary accruals is different from zero.

The binomial test was used to test which type of earnings management prevails in Central European companies. One-tailed test was used; a null hypothesis of a 51\% probability of upward earnings management occurring in companies compared to the alternative hypothesis that less than $51 \%$ of companies use earnings-enhancing accounting techniques.

The study used a sample of Central European companies whose financial data were obtained from the Amadeus database. Three selection criteria were used: the registered office of the company in a Central European country (the Czech Republic, Hungary, Poland, Slovakia), the value of total assets for the next four years (2016-2019) at least 2,000,000 Euro, and the value of turnover for 2019 at least 100,000 Euro. The gross sample contained 3754 companies and financial information from 2019. Winsoring at $1 \%$ and $99 \%$ was used to remove the extreme values, the advantage of which is to maintain the sample size. The overall sample of all Central European companies was divided according to two criteria: country and life cycle stage. All tests and hypotheses were applied to sub-samples of countries and sub-samples of the life cycle stage for a comprehensive analysis of earnings management in Central European companies and the answer to the question of whether the corporate life cycle affects earnings management.

\section{Results and Discussion}

The analysis of a sample of companies was the first step in the analysis. The gross sample contained 3754 companies. Missing values were present in the sample, so such observations were removed. Subsequently, outliers were analysed and removed by winsorizing to $1 \%$ and $99 \%$ percentiles. The advantage of this method is that the sample size is maintained. The net sample contained 3430 Central European companies corresponding to the conditions described in the Methods chapter. The life cycle stages were assigned according to the respective cash flow patterns in Table 1 and the earnings management proxies were estimated according to Eq. (2) - (3). Table 2 provides an overview of the descriptive statistics of the studied variables, distinguished by country and life cycle subsamples. 
Table 2 Descriptive statistics of earnings management proxies on country and life cycle subsamples

\begin{tabular}{|c|c|c|c|c|c|c|}
\hline & \multicolumn{3}{|c|}{ Modified Jones model } & \multicolumn{3}{c|}{ Teoh et al. model } \\
\hline country & Mean & Std. Dev. & \% of N & Mean & Std. Dev. & \% of N \\
\hline Czech Republic & 0,0358 & 0,1526 & $10,1 \%$ & 0,0340 & 0,1532 & $10,1 \%$ \\
\hline Hungary & 0,0279 & 0,1601 & $16,0 \%$ & 0,0262 & 0,1632 & $16,0 \%$ \\
\hline Poland & 0,0144 & 0,1423 & $58,6 \%$ & 0,0149 & 0,1449 & $58,6 \%$ \\
\hline Slovakia & 0,0252 & 0,1596 & $15,3 \%$ & 0,0175 & 0,1618 & $15,3 \%$ \\
\hline life cycle stage & Mean & Std. Dev. & \% of N & Mean & Std. Dev. & \% of N \\
\hline Introduction & 0,0250 & 0,1457 & $3,7 \%$ & 0,0345 & 0,1477 & $3,7 \%$ \\
\hline Growth & 0,0095 & 0,1138 & $23,0 \%$ & 0,0046 & 0,1215 & $23,0 \%$ \\
\hline Maturity & $-0,0139$ & 0,1398 & $13,3 \%$ & $-0,0217$ & 0,1416 & $13,3 \%$ \\
\hline Shake-out & 0,0096 & 0,1220 & $8,0 \%$ & 0,0045 & 0,1248 & $8,0 \%$ \\
\hline Decline & 0,0353 & 0,1665 & $52,0 \%$ & 0,0369 & 0,1665 & $52,0 \%$ \\
\hline
\end{tabular}

Source: author

The mean values of earnings management proxies in individual countries point to significant differences in the application of earnings management practices. The analysis shows that Czech companies are the most manipulated by profit in terms of total and shortterm discretionary accruals. On the contrary, although Polish companies increase profits on average, their discretionary accruals are the lowest among all the analysed countries. Both total and short-term accrual models show an overestimation of the accounting profit in the sample, but the values of the standard deviations show a high degree of variability, i.e. there is a high percentage of companies that reduce earnings. The values of total and short-term accruals are similar for all countries with the exception of Slovak companies. In these companies, on average, the value of total discretionary accruals is significantly higher than short-term accruals. This points out that frequent accounting manipulation techniques in Slovak companies include, for example, depreciation.

In terms of life cycle earnings management is U-shaped, similar to that reported by Hussain, et al. (2020). Declining companies are the most represented in the sample. Negative cash flow and the need to show a positive image of the company at this stage encourages managers to increase the accounting profit among all companies to the greatest extent. On the contrary, the relatively stable position of mature enterprises together with the minimum cost of capital is a suitable incentive to reduce reported earnings.

Last but not least, it should be noted that the standard deviations in all subsamples indicate a high degree of variability. This means that upward and downward earnings management are strongly represented in the subsamples, and the conclusions provided from the descriptive statistics may not be valid for all enterprises in Central European countries.

The Mann-Whitney U test was used to verify hypotheses H1 and H2 in the Literature review chapter. The test results are shown in Table 3. 
Table 3 Results of Mann-Whitney U test for country and life cycle subsamples

\begin{tabular}{|c|c|c|c|c|c|c|}
\hline & \multicolumn{3}{|c|}{ Modified Jones model } & \multicolumn{3}{c|}{ Teoh et al. model } \\
\hline & $\begin{array}{c}\text { Mann } \\
\text { Whitney } \\
\text { U }\end{array}$ & $\begin{array}{c}\text { Asymp. } \\
\text { Sig. (2- } \\
\text { tailed) }\end{array}$ & $\begin{array}{c}\text { Confirmed } \\
\text { hypothesis }\end{array}$ & $\begin{array}{c}\text { Mann } \\
\text { Whitney } \\
\text { U }\end{array}$ & $\begin{array}{c}\text { Asymp. } \\
\text { Sig. (2- } \\
\text { tailed) }\end{array}$ & $\begin{array}{c}\text { Confirmed } \\
\text { hypothesis }\end{array}$ \\
\hline Czech Republic & 52744,0 & 0,003 & H1 & 53091,0 & 0,004 & H1 \\
\hline Hungary & 278658,0 & 0,000 & H1 & 133164,0 & 0,001 & H1 \\
\hline Poland & 1968820,0 & 0,152 & H0 & 1980874,0 & 0,280 & H0 \\
\hline Slovakia & 123084,0 & 0,001 & H1 & 134656,0 & 0,424 & H0 \\
\hline & $\begin{array}{c}\text { Mann } \\
\text { Whitney } \\
\text { U }\end{array}$ & $\begin{array}{c}\text { Asymp. } \\
\text { Sig. (2- } \\
\text { tailed) }\end{array}$ & $\begin{array}{c}\text { Confirmed } \\
\text { hypothesis }\end{array}$ & $\begin{array}{c}\text { Mann } \\
\text { Whitney } \\
\text { U }\end{array}$ & $\begin{array}{c}\text { Asymp. } \\
\text { Sig. (2- } \\
\text { tailed) }\end{array}$ & $\begin{array}{c}\text { Confirmed } \\
\text { hypothesis }\end{array}$ \\
\hline Introduction & 8001,0 & 0,908 & H0 & 7239,0 & 0,132 & H0 \\
\hline Growth & 267810,0 & 0,000 & H1 & 278080,0 & 0,000 & H1 \\
\hline Maturity & 96460,0 & 0,057 & H0 & 98280,0 & 0,158 & H0 \\
\hline Shake-out & 27775,0 & 0,000 & H1 & 31900,0 & 0,001 & H1 \\
\hline Decline & 1577955,0 & 0,687 & H0 & 1558342,0 & 0,278 & H0 \\
\hline
\end{tabular}

Source: author

The results of the Mann-Whitney test indicate that companies in Central Europe manipulate profits unequally, so hypothesis H1 is rejected. Nevertheless, some partial hypotheses about earnings management in the analysed countries can be accepted. In the first place, Czech and Hungarian companies manipulate accounting earnings in terms of total and short-term accruals. On the contrary, Polish companies overestimate or underestimate profit over cash flow only to a very small extent, which was reflected in the rejection of the hypothesis of the presence of earnings management techniques in Polish companies. Slovak companies, similarly to the mean values, manipulate profits to a greater extent in the form of long-term discretionary accruals. This indicates that depreciation is an important part of the corporate management of Slovak companies in the form of a depreciation tax shield.

Hypothesis H2 states that Central European companies manipulate profits during the company's life cycle. On average, these companies apply accounting manipulations in the growth and shake-out stages. In other stages, the occurrence of earning management in companies was not confirmed. This indicates that it is growing and shake-out companies that have a high interest in creating a better and more stable picture of their financial performance to companies with different cash flow patterns.

The Mann-Whitney test confirmed that earnings management is present in some Central European economies, or in some stages of the life cycle. However, it is not clear whether accounting manipulations overestimate or underestimate earnings. Table 2 supports the hypothesis of the predominance of upward earnings management. The binomial test was used to test the probability of upward earnings management in subsamples of Czech, Hungarian total and short-term discretionary accruals and Slovak short-term accruals, or discretionary accruals of growing and shake-out companies. 
Table 4 Empirical proportions of upward and downward earnings management in the subsamples

\begin{tabular}{|c|c|c|c|c|}
\hline & \multicolumn{2}{|c|}{ Modified Jones model } & \multicolumn{2}{|c|}{ Teoh et al. model } \\
\hline country & $\begin{array}{c}\% \text { of upward } \\
\text { EM }\end{array}$ & $\begin{array}{c}\% \text { of downward } \\
\text { EM }\end{array}$ & $\%$ of upward EM & $\begin{array}{c}\text { \% of downward } \\
\text { EM }\end{array}$ \\
\hline Czech Republic & $56,2 \%$ & $43,8 \%$ & $55,91 \%$ & $44,09 \%$ \\
\hline Hungary & $57,3 \%$ & $42,7 \%$ & $55,66 \%$ & $44,34 \%$ \\
\hline Poland & $51,2 \%$ & $48,8 \%$ & $50,92 \%$ & $49,08 \%$ \\
\hline Slovakia & $55,5 \%$ & $44,5 \%$ & $51,33 \%$ & $48,67 \%$ \\
\hline life cycle stage & $\begin{array}{c}\text { \% of upward } \\
\text { EM }\end{array}$ & $\begin{array}{c}\% \text { of downward } \\
\text { EM }\end{array}$ & $\%$ of upward EM & $\begin{array}{c}\% \text { of downward } \\
\text { EM }\end{array}$ \\
\hline Introduction & $50,39 \%$ & $49,61 \%$ & $55,12 \%$ & $44,88 \%$ \\
\hline Growth & $57,09 \%$ & $42,91 \%$ & $55,44 \%$ & $44,56 \%$ \\
\hline Maturity & $53,41 \%$ & $46,59 \%$ & $47,47 \%$ & $52,53 \%$ \\
\hline Shake-out & $63,27 \%$ & $36,73 \%$ & $57,82 \%$ & $42,18 \%$ \\
\hline Decline & $50,36 \%$ & $49,64 \%$ & $50,98 \%$ & $49,02 \%$ \\
\hline
\end{tabular}

Source: author

Table 4 shows that the analysed companies make significant use of upward earnings management techniques; in the examined sub-samples (Czech Republic, Hungary, Slovakia, Growth and Shake-out) in more than $55 \%$ and $60 \%$ of cases, respectively. Therefore, the H0 binomial test hypothesis states that the probability of occurrence of positive discretionary accruals (upward earnings management) is 55\% (60\%) compared to the alternative hypothesis that upward earnings management occurs in less than $55 \%(60 \%)$. All hypotheses were verified at the $5 \%$ level of significance. The results of testing the investigated hypotheses are shown in Table 5.

Table 5 Results of binomial test for selected country and life cycle subsamples

\begin{tabular}{|c|c|c|c|c|c|c|}
\hline & \multicolumn{2}{|c|}{ Modified Jones model } & \multicolumn{3}{c|}{ Teoh et al. model } \\
\hline & $\begin{array}{c}\text { Tested } \\
\text { probability } \\
\text { of } \\
\text { country }\end{array}$ & $\begin{array}{c}\text { Asymp. } \\
\text { Sig. (1- } \\
\text { tailed) }\end{array}$ & $\begin{array}{c}\text { Confirmed } \\
\text { hypothesis }\end{array}$ & $\begin{array}{c}\text { Tested } \\
\text { probability } \\
\text { of } \\
\text { occurence }\end{array}$ & $\begin{array}{c}\text { Asymp. } \\
\text { Sig. (1- } \\
\text { tailed) }\end{array}$ & $\begin{array}{c}\text { Confirmed } \\
\text { hypothesis }\end{array}$ \\
\hline Czech Republic & $55 \%$ & 0,347 & H0 & $55 \%$ & 0,387 & H0 \\
\hline Hungary & $55 \%$ & 0,149 & H0 & $55 \%$ & 0,395 & H0 \\
\hline Slovakia & $55 \%$ & 0,424 & H0 & - & - & - \\
\hline life cycle stage & $\begin{array}{c}\text { Tested } \\
\text { probability } \\
\text { of } \\
\text { occurence }\end{array}$ & $\begin{array}{c}\text { Asymp. } \\
\text { Sig. (1- } \\
\text { tailed) }\end{array}$ & $\begin{array}{c}\text { Confirmed } \\
\text { hypothesis }\end{array}$ & $\begin{array}{c}\text { probability } \\
\text { of } \\
\text { occurence }\end{array}$ & $\begin{array}{c}\text { Asymp. } \\
\text { Sig. (1- } \\
\text { tailed) }\end{array}$ & $\begin{array}{c}\text { Confirmed } \\
\text { hypothesis }\end{array}$ \\
\hline Shake-out & $55 \%$ & 0,126 & H0 & $55 \%$ & 0,415 & H0 \\
\hline \multicolumn{2}{|c|}{$60 \%$} & 0,148 & H0 & $55 \%$ & 0,190 & H0 \\
\hline
\end{tabular}

Source: author

All in all, country affiliation, as well as specific cash flow patterns expressing the life cycle stage, significantly affect the rate of profit manipulation in Central European countries. 
While Polish companies manipulate profits to a small extent, in other Central European countries, accounting profit overestimates over cash flow predominantly; 5.5 out of 10 companies manipulate the accounting profit upwards. In terms of life cycle, the surveyed companies manipulate profits in the growth and shake-out stages, where upward earnings management techniques such as Cookie Jar reserve, Big Bath and others predominate. The motive for these techniques may be to stabilize the financial position in the growth phase of the company, or to reduce the cost of capital and reduce risk.

\section{Conclusions}

Macroeconomic and competitive conditions in today's global market mean that many companies are at high risk of financial distress. These conditions often encourage corporate managers to behave opportunistically and manipulate profits in favor of reporting a stable financial position or achieving significant tax benefits, especially in small pro-export oriented countries such as Central European emerging economies.

The study focused on a comprehensive analysis of the existence and extent of upward and downward earnings management in terms of countries and life cycle stages. In a sample of 3430 companies, the objectives of the study were verified by the Mann-Whitney U test and the binomial test. The descriptive characteristics of the examined sample indicate that earnings management is U-shaped during the life cycle, where mature companies significantly underestimate earnings, while start-ups and declining companies overestimate earnings. In terms of countries, all Central European companies in the sample apply upward earnings management techniques on average. However, these assumptions have not been verified for all Central European companies; upward earnings management is present in more than $50 \%$ of Czech, Hungarian and Slovak companies, polish companies on average do not manipulate profit or manipulate to a very small extent. Growing and declining companies in Central European economies tend to increase their profits, which is associated with creating a picture of a stable and efficient company in order to obtain advantageous debt covenants or reverse the company's bankruptcy.

The results of this study may be a suitable basis for evaluation and decision-making by corporate policy makers, resp. to estimate the real financial position of the company in competitive benchmarking. However, there are several limitations that should be considered. In the first place, only accrual earnings management was considered, so future research should focus on the analysis of real earnings management in terms of the corporate life cycle. Second, two proxies were used for earnings management; future research could explore other models of earnings management for a more comprehensive assessment of profit manipulation in Central European countries.

\section{Acknowledgements}

The paper is an output of scientific project VEGA 1/0210/19: Research of innovative attributes of quantitative and qualitative fundaments of the opportunistic earnings modelling.

\section{References}

1. Lisboa, I., \& Kacharava, A. (2018). Does Financial Crisis Impact Earnings Management: Evidence from Portuguese and UK. European Journal of Applied Business Management, $4(1), 80-100$. 
2. Iatridis, G. (2010). International Financial Reporting Standards and the quality of financial statement information. International Review of Financial Analysis, 43, 193204.

3. Habib, A., \& Hasan, M. M. (2017). Firm life cycle, corporate risk-taking and investor sentiment. Accounting \& Finance, 57(2), 456-497.

4. Hussain, A., Akbar, M., Khan, M. K., Akbar, A., Panait, M., \& Voica, M. C. (2020). When Does Earnings Management Matter? Evidence across the Corporate Life Cycle for Non-Financial Chinese Listed Companies. Journal of Risk and Financial Management, 13(12), 313.

5. Michalkova, L. (2021). Earnings quality and accruals over company's life cycle. SHS Web of Conferences, 92, 02043.

6. Suberi, A. Z. M., Hsu, G., \& Wyatt, A. (2012). The Relation between Firm Growth and Accounting Quality: A Test of the Life Cycle Hypothesis (Working Paper) Brisbane: University of Queensland, Australia.

7. Can, G. (2020). Do Life-Cycles Affect Financial Reporting Quality? Evidence from Emerging Market. Cogent Business \& Management, 7(1), 1854147.

8. Dickinson, V. (2011). Cash Flow Patterns as a Proxy for Firm Life Cycle. The Accounting Review, 86(6), 1969-1994.

9. McKee, T.E. (2005). Earnings Management: An Executive Perspective. Indiana: Thomson.

10. Kramarova, K., \& Valaskova, K. (2020). Application of chosen fraudulent detection technique in the Slovak business environment. SHS Web of Conferences, 74, 01019.

11. Svabova, L., Kramarova, K., Chutka, J., \& Strakova, L. (2020). Detecting earnings manipulation and fraudulent financial reporting in Slovakia. Oeconomia Copernicana, 11(3), 485-508.

12. Kliestik, T., Belas, J., Valaskova, K., Nica, E., \& Durana, P. (2020). Earnings management in V4 countries: the evidence of earnings smoothing and inflating, Economic Research-Ekonomska Istraživanja.

13. Lizinska, J., \& Czapiewski, L. (2018). Towards Economic Corporate Sustainability in Reporting: What Does Earnings Management around Equity Offerings Mean for LongTerm Performance? Sustainability, 10(12), 4349.

14. Savova, K. (2021). Variable application of accounting standards - current aspects, Ekonomicko-manazerske spektrum, 15(1), 111-122.

15. Sadiq, M., Pantamee, A. A., Mohamad, S., Aldeehani, T. M., \& Ady, S. U. (2020). Corporate governance and earnings management: evidence from listed non-financial firms. Polish Journal of Management Studies, 22(2), 456-469.

16. Siekelova, A., Belas, J., Podhorska, I., Durana, P. (2021). Accrual-Based Earnings Management: A Case Study in V4 Focusing on Mining And Quarrying Sector. Acta Montanastica, Slovaca, 26(1), 70-83.

17. Damodaran, A. (2018). The corporate life cycle: growing up is hard to do! People.Stern. http://people.stern.nyu.edu/adamodar/pdfiles/country/corporatelifecycleLongX.pdf

18. Kramolis, J., \& Dobes, K. (2020). Debt as a financial risk factor in SMEs in the Czech Republic. Equilibrium. Quarterly Journal of Economics and Economic Policy, 15(1), 87-105.

19. Valaskova, K., Adamko, P., Frajtova-Michalikova, K., \& Macek, J. (2021). Quo Vadis earnings management? Analysis of manipulation determinants in Central European environment. Oeconomia Copernicana,12(3). 
20. Bilan, S., Melas, D., \& Melasova, K. (2020). Identifying manager's aspects associated with company's income through the point-bisserial correlation: The middle Europe example. Ekonomicko-manazerske spektrum, 14(1), 1-9.

21. Edwards, A., Schwab, C., \& Shevlin, T. (2016). Financial constraints and cash tax savings. The Accounting Review, 91(3), 859-881.

22. Zamrudah, R., \& Salman, K. R. (2013). Earnings management prediction (a study of company's life cycle). The Indonesian Accounting Review, 3(2), 107-120.

23. Dickinson, V., Kassa, H., \& Schaberl, P. D. (2018). What information matters to investors at different stages of a firm's life cycle? Advances in Accounting, 42, 22-33.

24. Gray-Hawkins, M., \& Lăzăroiu, G. (2020). Industrial Artificial Intelligence, Sustainable Product Lifecycle Management, and Internet of Things Sensing Networks in CyberPhysical Smart Manufacturing Systems. Journal of Self-Governance and Management Economics, 8(4): 19-28. 